\title{
STUDY OF THE RATIO OF CROSS-MATCHING TO TRANSFUSION OF BLOOD OR BLOOD COMPONENT, I.E. PACKED RED BLOOD CORPUSCLES TO DEVELOP GOOD PRACTICES FOR THE UTILISATION OF BLOOD
}

Kanika Bansal', Rakesh Kakkar ${ }^{2}$

${ }_{1}^{1}$ MBBS Student, Bharti Vidyapeeth Deemed University Medical College, Pune.

2 Professor and Senior Consultant, Department of Pathology, IQ City, Durgapur.

ABSTRACT
BACKGROUND
Blood ordering is a common practice in surgical and non-surgical field, the average requirement for a particular procedure is
usually based on subjective anticipation of blood loss rather than on evidence based estimates. Over-ordering with minimal
utilisation squanders technical time, reagent and imposes extra expenses on patients. Therefore, the aim of the study was to
calculate the ratio of cross-matching to transfusion.

\section{MATERIALS AND METHODS}

Observational study was conducted in Bharti Hospital. Two-month data were collected from Blood Bank registers. Blood utilisation was calculated using cross-match to transfusion ratio.

\section{RESULTS}

A total of 997 units cross-matched. The maximum cross-match and transfusion was made of packed red blood corpuscles, followed by fresh frozen plasma and random donor platelet. The cross-match to transfusion ratio in non-surgical and surgical setup seen was 1.008 and 1.012 respectively. Maximum department-wise cross-match and transfusion was made by:

1. Gynaecology department: Packed red blood corpuscles.

2. Surgery department: Fresh frozen plasma.

3. Medicine department: Random donor platelet.

The cross-match to transfusion ratio is 1.010 .

\section{CONCLUSION}

The overall blood utilisation was efficient, yet to achieve a ratio of 1.0 the hospital can implement maximum surgical blood ordering schedule for elective surgical procedures and conduct regular auditing.

\section{KEYWORDS}

Blood Component Transfusion, Blood Transfusion, Cross-Matching to Transfusion Ratio, India.

HOW TO CITE THIS ARTICLE: Bansal K, Kakkar R. Study of the ratio of cross-matching to transfusion of blood or blood component, i.e. packed red blood corpuscles to develop good practices for the utilisation of blood. J. Evolution Med. Dent. Sci. 2017;6(35):2909-2914, DOI: 10.14260/Jemds/2017/627

\section{BACKGROUND}

Blood is the very lifeline of our body. Wastage of blood, however unintentional is like wasting a very important resource. For surgical operations, a doctor pre-orders blood bags and blood components to be ready for the worst case scenario, demanding large quantities of blood or overestimating the anticipated blood loss, of which a meagre amount is put to use. Injudicious pre-operative over-ordering of blood burdens the physical and human resources of the healthcare facility and increases the cost of medical care. On the one hand, we have so many campaigns every year for donation of blood to fulfil the increasing demand and on the

Financial or Other, Competing Interest: None.

Submission 18-03-2017, Peer Review 19-04-2017,

Acceptance 25-04-2017, Published 01-05-2017.

Corresponding Author:

Kanika Bansal,

D-1501, One North, Behind Seasons Mall,

Magarpatta City, Pune-411028,

Maharashtra, India.

E-mail: bansalkanika96@gmail.com setsfunctionsorganichemistry@gmail.com

DOI: $10.14260 /$ jemds $/ 2017 / 627$ other there is an outrageous wastage of blood in both surgical and non-surgical units. In a country like India where there is a large disparity between the rich and the poor, many people who undergo surgeries are not very well to do and over-ordering of blood and its components unnecessarily adds up to their healthcare bills. A review of the surgical blood ordering practice should be mandatory.

The request of blood units, in a non-surgical or a surgical setup is usually based on the worst case assumptions, demanding large quantities of blood or overestimating the anticipated loss, of which little is ultimately used.[1] This may exhaust the valuable supplies and resources both in technician time, effort and biochemical reagents. Also, adds up a financial burden for each patient undergoing a procedure.[2] Increasing demand for blood and blood products together with the rising cost and the transfusion associated morbidity led to various studies that reviewed blood ordering and transfusion practice. ${ }^{[3,4]}$ The availability of donors at short notice is not up to mark in our country.

In addition, a number of studies in many countries of the world have shown over-ordering of blood by surgeons with utilisation ranging from 5 to $40 \%{ }^{[3]}$ In South Africa, for example, $7-10 \%$ of blood is wasted annually because of excessive ordering of blood. ${ }^{[5]}$ Reports from India, Kuwait and 
Nigeria also showed utilisation rate of $28 \%, 13.6 \%$ and $69.7 \%$ respectively.[1],[6],[2] However, similar studies have not been conducted for other non-surgical departments of the hospitals anywhere in India or elsewhere. So, this study will bring out a realistic picture of the ordering done by surgical and non-surgical branches.

A number of indices are used to determine the efficiency of blood ordering and utilisation system. Boral Henry was the first who suggested the use of cross-match to transfusion ratio (C/T ratio) in 1975.[3] Consequently, a number of authors used $\mathrm{C} / \mathrm{T}$ ratio for evaluating blood transfusion practice. Ideally, this ratio should be 1.0 , but a ratio of 2.5 and below was suggested to be indicative of efficient blood usage.[2]

Evaluating blood ordering and transfusion practices and subsequent developing of a blood ordering schedule, which serves as a guide to anticipated normal blood usage for elective and emergency procedures can decrease excessive ordering of blood.[7] Bharati Vidyapeeth Deemed University Medical College, Pune has a hospital of its own, which has a Blood Centre which caters to the needs of the patients. There are regular voluntary blood collection campaigns taking place to fulfil the requirement of the hospital. Therefore, the aim of the study was to calculate the ratio of cross-matching to transfusion of whole blood or blood component, i.e. Packed Red Blood Corpuscles (WB/PRBC) to develop good practices and their utilisation. The objectives to be covered by this study are as follows-

1. To calculate the cross-match to transfusion ratio.

2. To observe the number of units of whole blood and components of blood demanded and issued.

3. To calculate the cross-match to transfusion ratio of nonsurgical and surgical departments.

4. To observe department-wise demand and issue of blood or blood component.

[Non-Surgical: Medicine, Paediatrics, Gynaecology only normal delivery. Surgical-Surgery, Gynaecology only Csection and any other department which requires WB/PRBC during surgery].

\section{MATERIALS AND METHODS}

A hospital based observational study was conducted in those patients who required blood or blood component like:

\begin{tabular}{|c|c|c|c|}
\hline $\begin{array}{c}\text { Sl. } \\
\text { No. }\end{array}$ & $\begin{array}{c}\text { Blood or Blood } \\
\text { Component Available }\end{array}$ & $\begin{array}{c}\text { Short form Used } \\
\text { in the Register }\end{array}$ & $\begin{array}{c}\text { Technique } \\
\text { Used }\end{array}$ \\
\hline 1. & Whole Human Blood & WB & $\begin{array}{c}\text { Cross- } \\
\text { matching }\end{array}$ \\
\hline 2. & $\begin{array}{c}\text { Packed Red Blood } \\
\text { Corpuscles }\end{array}$ & PRBC & $\begin{array}{c}\text { Cross- } \\
\text { matching }\end{array}$ \\
\hline 3. & Fresh Frozen Plasma & FFP & $\begin{array}{c}\text { Reverse } \\
\text { grouping }\end{array}$ \\
\hline 4. & $\begin{array}{c}\text { Platelet Concentrate } \\
\text { (Random Donor } \\
\text { Platelet) }\end{array}$ & RDP & $\begin{array}{c}\text { Group to } \\
\text { group }\end{array}$ \\
\hline 5. & $\begin{array}{c}\text { Platelet Concentrate } \\
\text { (Platelet Apheresis) }\end{array}$ & SDP & $\begin{array}{c}\text { Group to } \\
\text { group }\end{array}$ \\
\hline 6. & $\begin{array}{c}\text { Cryoprecipitated } \\
\text { Antihaemophilic Factor }\end{array}$ & CRYO & $\begin{array}{c}\text { Group to } \\
\text { group }\end{array}$ \\
\hline \multicolumn{3}{|c|}{ Table 1 } \\
\hline
\end{tabular}

Cross-match to transfusion ratio was not calculated for FFP, RDP, SDP, CRYO as cross-matching was not done between the patient's blood and those components.
All patients at Bharati Hospital, Pune who required transfusion were considered over a period of two months



Ethical clearance was taken from Ethical Board of Bharati Vidyapeeth Deemed University Medical College, Pune. Confidentiality of the information was assured by using code numbers than personal identification and keeping data inaccessible.

A prior permission was taken from the medical director and the blood centre in-charge of the hospital. A predesigned, semi-structured, self-administered data-sheet was used to collect the data from the blood centre.

Patient's reference number, whole blood or component of blood demanded, non-surgical or surgical department, wastage of blood if any, cause of wastage of blood was noted from the blood bank registers.

Data was coded, entered and analysed using Microsoft Excel Worksheet 2010. The result was computed with the following equation-

1. Cross-match to transfusion ratio $(\mathrm{C} / \mathrm{T}$ ratio $)=$ number of units cross-matched/number of units transfused. The obtained data was evaluated and presented in the form of bar graphs and pie charts. The following characteristics were highlighted using frequency and percentage-

1. Whether whole blood or component of blood was transfused.

2. Utilisation by non-surgical or surgical department.

\section{Study Tool \\ Data Sheet \\ Ref. No.}

Department:

Whole blood/component of blood: (if component of blood then please specify)

A. Non-surgical:

B. Surgical:

Total units prepared:

Total units cross matched:

Total units transfused:

Wastage of blood: Yes/No

\section{RESULTS}

The cross-matching to transfusion ratio is 1.010 , as in the study period 997 units of blood were cross-matched and 987 units of blood were transfused.

\begin{tabular}{|c|c|c|}
\hline $\begin{array}{c}\text { Blood Units } \\
\text { Cross-Matched }\end{array}$ & $\begin{array}{c}\text { Blood Units } \\
\text { Transfused }\end{array}$ & $\begin{array}{c}\text { Cross-Match to } \\
\text { Transfusion Ratio (C/T) }\end{array}$ \\
\hline 997 & 987 & 1.010 \\
\hline \multicolumn{3}{|c|}{ Table 2} \\
\hline
\end{tabular}

1. Distribution of demand and issue of different blood components- During the study period it was observed that maximum cross-match and transfusion was done of PRBC, i.e. 997 and 987 units respectively. (Refer to Fig. $1.1,1.2,1.3,1.4,1.5$ and 1.6). 


\begin{tabular}{|c|c|c|}
\hline $\begin{array}{c}\text { Blood } \\
\text { Components }\end{array}$ & $\begin{array}{c}\text { No. of Units } \\
\text { Demanded }\end{array}$ & $\begin{array}{c}\text { No. of Units } \\
\text { Issued }\end{array}$ \\
\hline PRBC & 997 & 987 \\
\hline FFP & 347 & 282 \\
\hline RDP & 384 & 243 \\
\hline SDP & 0 & 0 \\
\hline CRYO & 0 & 0 \\
\hline \multicolumn{3}{|c}{ Table 3 } \\
\hline
\end{tabular}

Figure 1.1

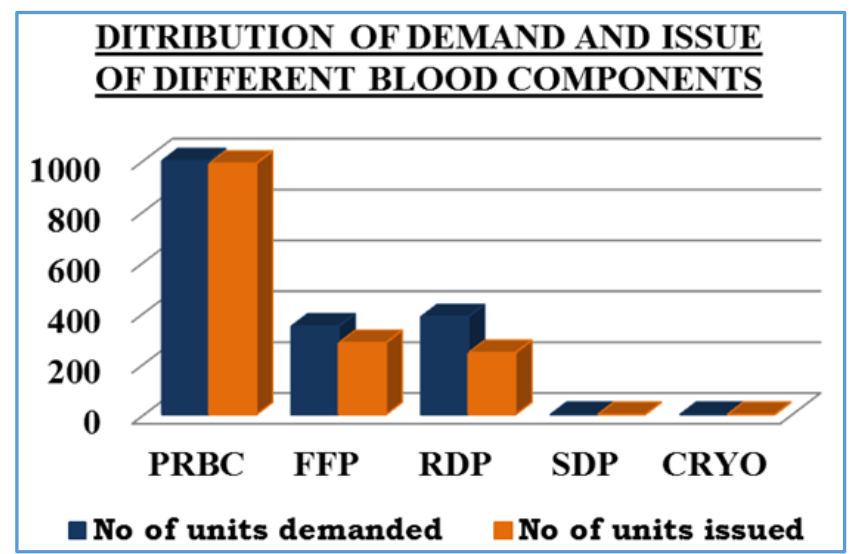

Figure 1.2

\begin{tabular}{|c|c|c|}
\hline $\begin{array}{c}\text { Blood } \\
\text { Components }\end{array}$ & $\begin{array}{c}\text { No. of Units } \\
\text { Demanded }\end{array}$ & Percentage \\
\hline PRBC & 997 & $58 \%$ \\
\hline FFP & 347 & $20 \%$ \\
\hline RDP & 384 & $22 \%$ \\
\hline SDP & 0 & $0 \%$ \\
\hline CRYO & 0 & $0 \%$ \\
\hline \multicolumn{3}{|c|}{ Table 4 } \\
\hline
\end{tabular}

Figure 1.3

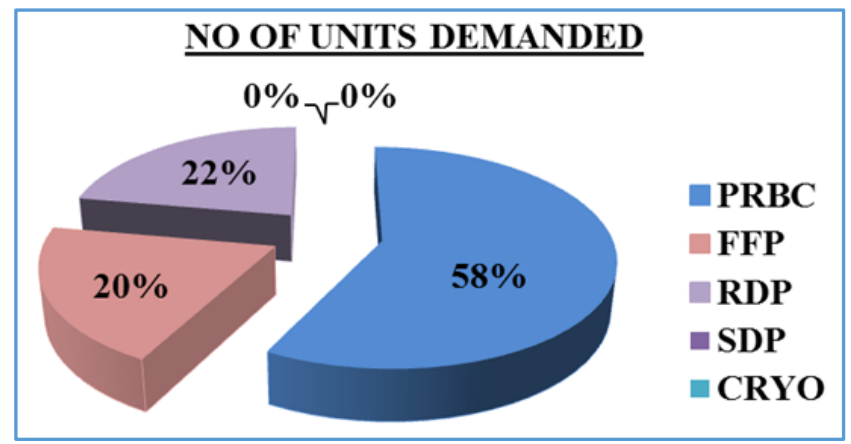

Figure 1.4

\begin{tabular}{|c|c|c|}
\hline Blood Components & No. of Units Issued & Percentage \\
\hline PRBC & 987 & $65 \%$ \\
\hline FFP & 282 & $19 \%$ \\
\hline RDP & 243 & $16 \%$ \\
\hline SDP & 0 & $0 \%$ \\
\hline CRYO & 0 & $0 \%$ \\
\hline \multicolumn{3}{|c|}{ Table 5 } \\
\hline
\end{tabular}

The pie chart present tries to depict the total units demanded were 1728 units, out of which $58 \%$ is PRBC i.e. 997 units, $20 \%$ is FFP i.e. 347 units and $22 \%$ is RDP i.e. 384 units.

Figure 1.5

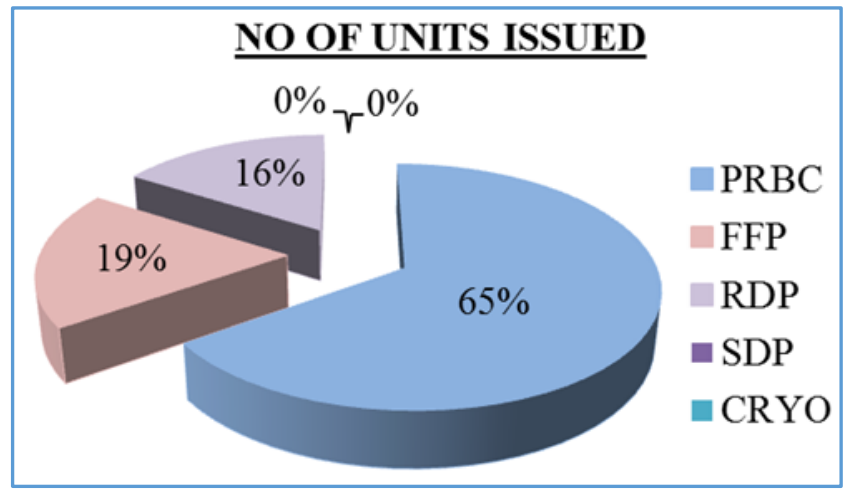

Figure 1.6

The pie chart present tries to depict the total units issued were 1512 units, out of which $65 \%$ is PRBC i.e. 987 units, $19 \%$ is FFP i.e. 282 units and $16 \%$ is RDP i.e. 243 units.

2. Cross-match to transfusion ratio (C/T) of nonsurgical and surgical Departments- Number of units cross-matched and transfused in non-surgical departments is 678 and 672 respectively. Therefore, the ratio is 1.008. Number of units cross-matched and transfused in surgical department is 319 and 315 respectively. Therefore, the ratio is 1.012. (Refer to Fig. 2.1).

\begin{tabular}{|c|c|c|c|}
\hline Departments & $\begin{array}{c}\text { No. of Units } \\
\text { Cross- } \\
\text { Matched }\end{array}$ & $\begin{array}{c}\text { No. of Units } \\
\text { Transfused }\end{array}$ & $\begin{array}{c}\text { Cross-match to } \\
\text { Transfusion } \\
\text { Ratio (C/T) }\end{array}$ \\
\hline Non-Surgical & 678 & 672 & 1.008 \\
\hline Surgical & 319 & 315 & 1.012 \\
\hline \multicolumn{4}{|c|}{ Table 6 } \\
\hline
\end{tabular}

\section{Figure 2.1}

3. Department-wise distribution of demand and issue of various blood components- During the study, it was observed that maximum demand was made of:

- PRBC: $40 \%$ units by the Gynaecology department followed by the Paediatrics (22\%) and Medicine (20\%).

- $\quad$ FFP: $39 \%$ units by the Surgery department followed by the Gynaecology (22\%) and Paediatrics (19\%).

- $\quad$ RDP: $48 \%$ units by the Medicine department followed by the Paediatrics (14\%).

It was also observed that maximum issue was-

- PRBC: $40 \%$ units by the Gynaecology department followed by the Paediatrics (22\%) and Medicine (20\%).

- FFP: $46 \%$ units by the Surgery department followed by the Paediatrics (18\%) and Gynaecology (18\%).

- $\quad$ RDP: $43 \%$ units by the Medicine department followed by the Paediatrics (34\%). (Refer to Fig. 3.1, 3.2, 3.3, 3.4, 3.5, $3.6,3.7,3.8,3.9,3.10,3.11,3.12,3.13,3.14,3.15$ and 3.16). 


\begin{tabular}{|c|c|c|c|c|c|}
\hline & 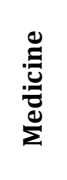 & 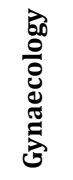 & 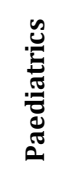 & 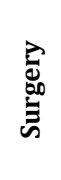 & 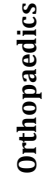 \\
\hline PRBC & 200 & 396 & 214 & 123 & 64 \\
\hline FFP & 42 & 75 & 67 & 136 & 27 \\
\hline RDP & 186 & 16 & 122 & 52 & 8 \\
\hline SDP & 0 & 0 & 0 & 0 & 0 \\
\hline CRYO & 0 & 0 & 0 & 0 & 0 \\
\hline
\end{tabular}

Figure 3.1

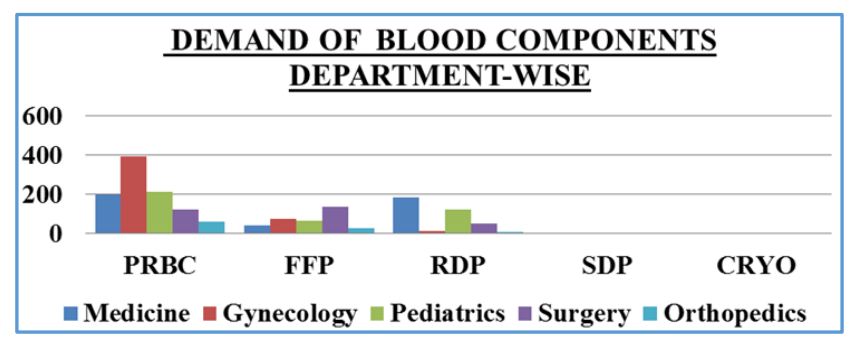

Figure 3.2

\begin{tabular}{|c|c|c|}
\hline Department & PRBC & Percentage \\
\hline Medicine & 200 & $20 \%$ \\
\hline Gynaecology & 396 & $40 \%$ \\
\hline Paediatrics & 214 & $22 \%$ \\
\hline Surgery & 123 & $12 \%$ \\
\hline Orthopaedics & 64 & $6 \%$ \\
\hline \multicolumn{3}{|c|}{ Table 8 } \\
\hline
\end{tabular}

Figure 3.3

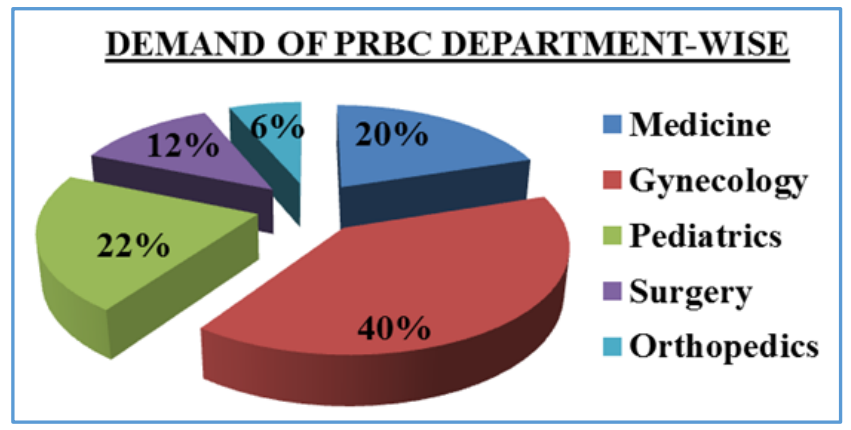

Figure 3.4

\begin{tabular}{|c|c|c|}
\hline Department & FFP & Percentage \\
\hline Medicine & 42 & $12 \%$ \\
\hline Gynaecology & 75 & $22 \%$ \\
\hline Paediatrics & 67 & $19 \%$ \\
\hline Surgery & 136 & $39 \%$ \\
\hline Orthopaedics & 27 & $8 \%$ \\
\hline \multicolumn{3}{|c|}{ Table 9 } \\
\hline
\end{tabular}

Figure 3.5

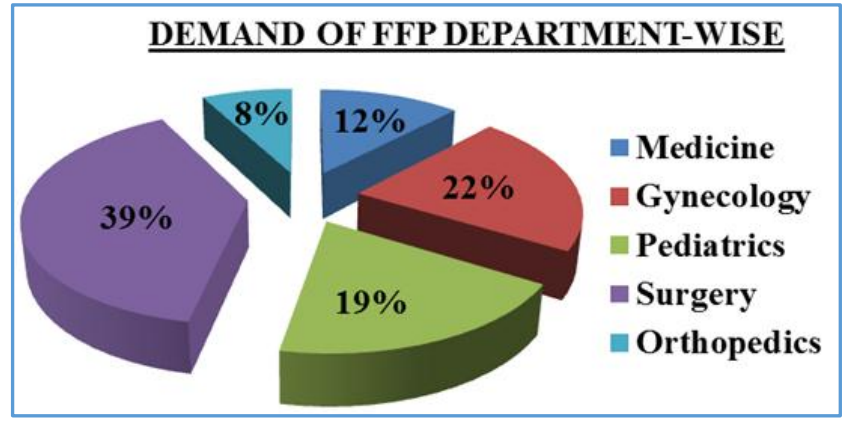

Figure 3.6

\begin{tabular}{|c|c|c|}
\hline Department & RDP & Percentage \\
\hline Medicine & 186 & $48 \%$ \\
\hline Gynaecology & 16 & $4 \%$ \\
\hline Paediatrics & 122 & $32 \%$ \\
\hline Surgery & 52 & $14 \%$ \\
\hline Orthopaedics & 8 & $2 \%$ \\
\hline \multicolumn{3}{|c|}{ Table 10 } \\
\hline
\end{tabular}

\section{Figure 3.7}

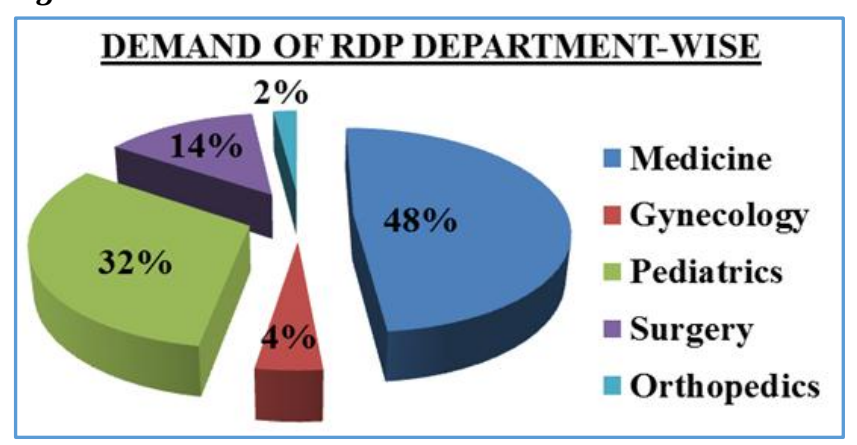

Figure 3.8

\begin{tabular}{|c|c|c|c|c|c|}
\hline & 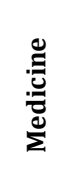 & 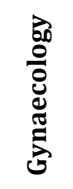 & 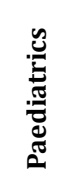 & 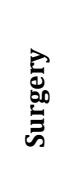 & 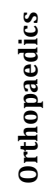 \\
\hline PRBC & 196 & 396 & 212 & 120 & 63 \\
\hline FFP & 34 & 50 & 51 & 129 & 18 \\
\hline RDP & 104 & 12 & 83 & 40 & 4 \\
\hline SDP & 0 & 0 & 0 & 0 & 0 \\
\hline CYRO & 0 & 0 & 0 & 0 & 0 \\
\hline \multicolumn{6}{|c|}{ Table 11} \\
\hline
\end{tabular}

Figure 3.9

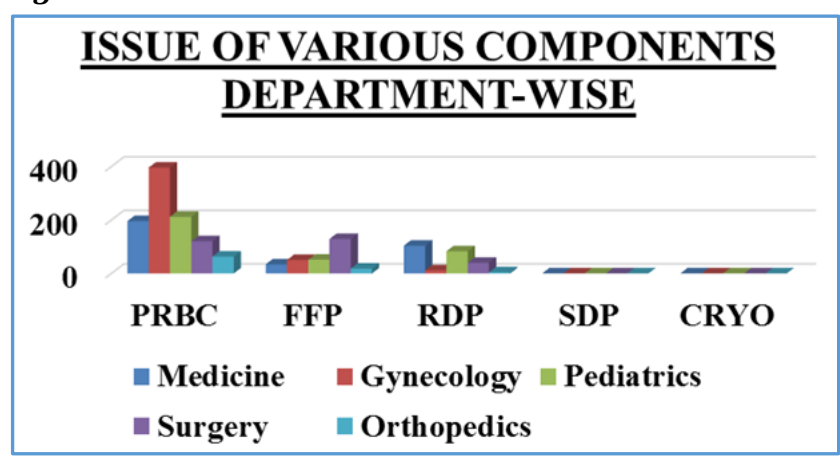


Figure 3.10

\begin{tabular}{|c|c|c|}
\hline Department & PRBC & Percentage \\
\hline Medicine & 196 & $20 \%$ \\
\hline Gynaecology & 396 & $40 \%$ \\
\hline Paediatrics & 212 & $22 \%$ \\
\hline Surgery & 120 & $12 \%$ \\
\hline Orthopaedics & 63 & $6 \%$ \\
\hline \multicolumn{3}{|c|}{ Table 12 }
\end{tabular}

Figure 3.11

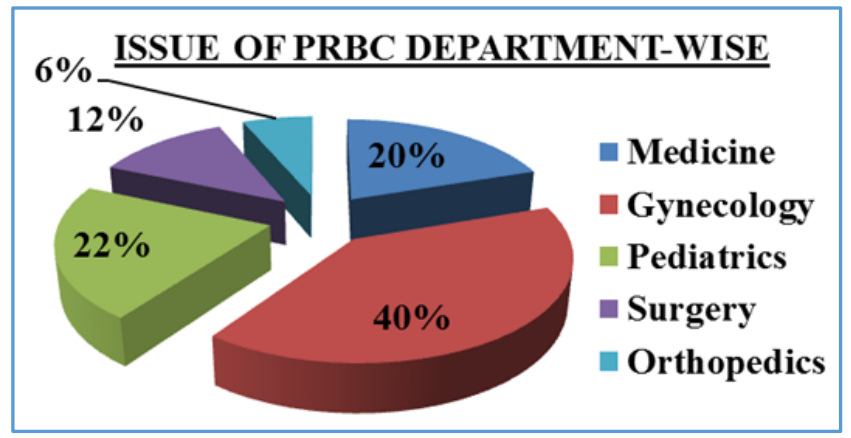

Figure 3.12

\begin{tabular}{|c|c|c|}
\hline Department & FFP & Percentage \\
\hline Medicine & 34 & $12 \%$ \\
\hline Gynaecology & 50 & $18 \%$ \\
\hline Paediatrics & 51 & $18 \%$ \\
\hline Surgery & 129 & $46 \%$ \\
\hline Orthopaedics & 18 & $6 \%$ \\
\hline \multicolumn{3}{|c|}{ Table 13 } \\
\hline
\end{tabular}

Figure 3.13

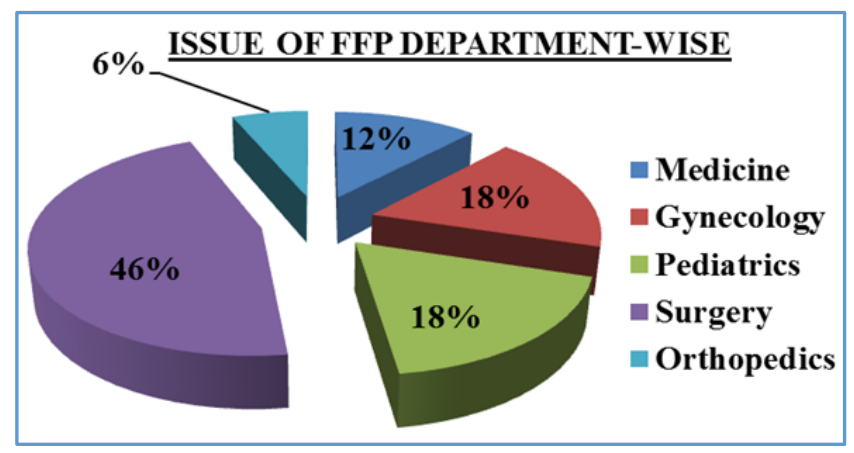

Figure 3.14

\begin{tabular}{|c|c|c|}
\hline Department & RDP & Percentage \\
\hline Medicine & 104 & $43 \%$ \\
\hline Gynaecology & 12 & $5 \%$ \\
\hline Paediatrics & 83 & $34 \%$ \\
\hline Surgery & 40 & $16 \%$ \\
\hline Orthopaedics & 4 & $2 \%$ \\
\hline \multicolumn{3}{|c}{ Table 14 } \\
\hline
\end{tabular}

Figure 3.15

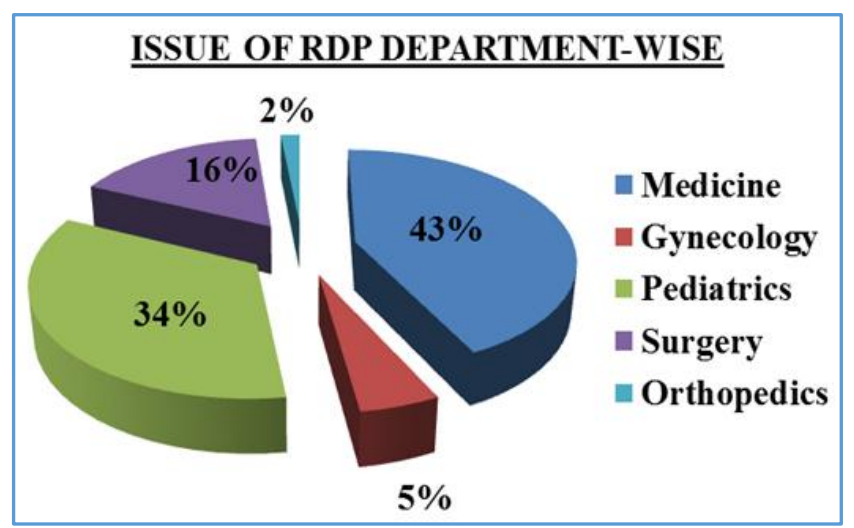

Figure 3.16

\section{DISCUSSION}

WB/PRBC is crucial in patient care, but they are in limited supply and have significant associated risks and costs. Blood transfusion no doubt plays a major role in the resuscitation and management of the patients, but doctors while preparing for the worst tend to overestimate the anticipated blood. There is a limited supply with increasing demand and underutilisation of the requested blood worldwide.

Pre-operative over-ordering of blood has been documented since 1976, when Friedman et al published their findings. Subsequently, a number of studies have also showed over-ordering of blood in different countries.[1,3] Data from developing countries have shown gross over-ordering of blood.[3] Since the introduction of blood transfusion into clinical practice, its appropriate use has been the subject of debate. It has been reported that only $30 \%$ of cross-matched blood is used in elective surgery. ${ }^{[8]}$ Therefore, it is essential that the usage of blood and blood products should be rationalised and saved for critical situations. [7]

According to this recommendation, the cross-match to transfusion ratio of 1.010 that is reported in the current study indicates efficient blood usage. This ratio was lower than that reported by studies conducted in Nigeria (2.2), India (2.5), Egypt (3.9)[2],[9],[10] and Malaysia (5.0).[11]

\section{CONCLUSION}

The ratio of cross-matching to transfusion is optimal as compared with the figures in the literature. Commonly demanded and issued components were PRBC, FFP and RDP. Cross-matching to transfusion ratio of non-surgical and surgical departments was 1.008 and 1.012, respectively. Gynaecology department demanded and issued the highest number of PRBC (396 and 396 units respectively) followed by Paediatrics and Medicine. Surgery department demanded and issued the maximum units of FFP (136 and 129 units respectively) followed by the Gynaecology and Paediatrics. Medicine department demanded and issued the highest units of RDP (186 and 104 units respectively) followed by the Paediatrics department. WB, SDP and CRYO were not issued to any of the patients. Generally, the blood is ordered by the residents present in the hospital. No wastage of blood was seen during the study period.

PRBC is generally cross-matched and then transfused. Only during emergency cases, if the doctor gives a written consent then PRBC is issued without cross-matching. FFP is 
issued group to group, therefore it is mandatory for every blood centre to have every blood group FFP in stock available. Platelets are only cross-matched if and only if they are reddish in colour.

To achieve standard value of cross-match to transfusion ratio, it is mandatory for the blood centre to prevent any contamination to take place and also to carry out procedures in appropriate manner.

To achieve the optimum value, i.e. 1.0 of cross-match to transfusion ratio on regular basis every hospital should apply Maximum Surgical Blood Ordering Schedule (MSBOS).

It serves as the guideline to anticipate normal blood usage for cold surgical procedures with the intention to relate the ordering of blood to the likelihood that the transfusion will be required.[2] The principle is based on to decrease the quantity of blood being cross-matched, by assigning each elective surgical procedure a tariff of transfusion.

\section{ACKNOWLEDGMENT}

I would sincerely like to thank my college, Bharati Vidyapeeth Deemed University Medical College, Pune and Bharati Hospital, Pune for giving me this opportunity to carry out my research.

Also, I would like to thank the Department of Blood Transfusion and Department of Pathology.

I am grateful to the staff of the hospital, my parents and my sister for helping me to complete my study.

\section{REFERENCES}

[1] Vibhute M, Kamath SK, Shetty A. Blood utilisation in elective general surgery cases: requirements, ordering and transfusion practices. J Postgrad Med 2000;46(1): 13-7.

[2] Olawumi HO, Bolaji BO. Blood utilisation in elective surgical procedure in Ilorin. Tropical Journal of Health Sciences 2006;13(1):15-7.
[3] Friedman BA, Oberman HA, Chadwick AR, et al. The maximum surgical blood order schedule and surgical blood use in United States. Transfusion 1976;16(4):380-7.

[4] Silberstein LE, Kruskall MS, Stehlingetal LC, et al. Strategies for the review of transfusion practices. JAMA 1989;262(14):1993-7.

[5] Efraim K. Blood conservation in South Africa. A vital need. Bloodless Medicine and Surgery 2001;43:7-9.

[6] Basnet RB, Lamichhane D, Sharma VK. A study of blood requisition and transfusion practice in surgery at Bir hospital. Postgraduate Medical Journal of NAMS 2009;9(2):14-9.

[7] Belayneh T, Messeles G, Abdissa Z, et al. Blood requisition and utilisation practice in surgical patients at university of Gondhar hospital, Northwest Ethopia. Journal of Blood Transfusion 2013;Article ID 758910:5.

[8] Sowayan SA. Use of blood in elective surgery: an area of wasted hospital resource. Ann Saudi Med 1994;14(4):326-8.

[9] Subramanian A, Sagar S, Kumar S, et al. Maximum surgical blood ordering schedule in a tertiary trauma centre in northern India: a proposal. J Emerg Trauma Shock 2012;5(4):321-7.

[10] Ibrahim SZ, Mamdouh HM, Ramadan AM. Blood utilization for elective surgeries at main University Hospital in Alexandria, Egypt. Journal of American Science 2011;7(6):683-9.

[11] Jayaranee S, Prathiba R, Vasanthi N, et al. An analysis of blood utilization for elective surgery in a tertiary medical centre in Malaysia. Malaysian J Pathol 2002;24(1):59-66. 